\title{
SCHOOL EDUCATION IN THE CONTEXT OF INCLUSIVE EDUCATION POLICIES
}

\author{
Ph.D. Gabriela Alina ANGHEL ${ }^{1}$, \\ Ph.D. Mariana DOGARU⿱ ${ }^{2}$,
}

Faculty of Theology and Sciences of Education, Valahia University of Târgovişte Polytechnic University Bucharest, Department for Initial Teachers Training, Bucharest ROMANIA

Email ${ }^{1}$ : anghelalina2002@yahoo.com

Email²: dogarumar@yahoo.com

\begin{abstract}
This article aims to explore strategies for inclusive education policy in Romania. To this were analyzed indicators on the coverage of the school-age population identified as a population with special educational needs and integrated into mainstream education. In line with inclusive education policies in Romania was performed and an analysis of strategies for achieving inclusion process of people with special educational needs in mainstream schools in Romania. Research methodology turned to the following research techniques: analysis of legal documents describing the policy of inclusion in mainstream education of children with special educational needs, secondary analysis of statistical data on the number of children with special educational needs integrated into mainstream education, analysis quality indicators specific integration into mainstream education of children with special educational needs. The findings reflected the following: there is political inclusion in mainstream schools for children with special educational needs and are provided strategies for attracting and keeping the mass education of this category of persons. Quality education for this category of persons is subject to fundamental operation of multidisciplinary teams at each school and adult education institutions on observance of the right to education for all.
\end{abstract}

Keywords: education; inclusion; inclusive school; equal opportunities

\section{INTRODUCTION}

Inclusive education described in the context of considering the paradigm of education for all, characterized by: inclusive learning environment and quality education for all children, irrespective of: social status, minority, cultural and intellectual development performance. Statement from Salamanca ${ }^{1}$ (1994) definition includes all children "all children, whether , children with disabilities, gifted children, homeless children, children from remote or belonging to nomadic groups, children belonging to linguistic minorities, ethnic or cultural children HIV or belonging to any other vulnerable groups ". Education in postmodern society highlights the need for achievement whenever an educational process based on non-discrimination and equal opportunities, the uniqueness and dignity of every

\footnotetext{
${ }^{1}$ UNESCO, Statement from Salamanca and the action for the education of persons with special needs adopted at the World Conference on "Education for people with special needs: access and quality", Salamanca, Spain, June 7 to 10, 1994
} 
child to quality education for all. It is estimated that education quality in the context of inclusive education is analyzed from the perspective of educational resources exploitation to create learning opportunities for each student. The social systems identify structures that have different representations of special educational needs issues, which includes most often a derogatory record. In public space, identify: discriminatory views against the prospect of integration into mainstream education of children with special educational needs, extensive reviews wary opposite the perspective of integration and social inclusion. Moreover, the term, special educational needs "in the common sense, placing explanation about matters covered by this disability, defect or failure of a person. These children are identified and referred to children with disabilities, "phrase stigmatizing behaviors associated with the development of type stigmatization, marginalization and social exclusion. Examples of social space we gave and still gives us pictures or speeches by parents of children with disabilities severely affected by denial of their children emotionally by those who consider that they are children or adults, normal ". Within the society, special educational requirements overlap with education for children with disabilities to integrate and social functioning within the normal limits. Stigma and denial of such children is justified in the context of poor mentality of parents regarding the negative impact on the education of their own children, knowing about the problems faced by children with special needs. It is considered that in Romania there are 71798 children with disabilities. Of these, 46661 are situated in the segment of school age between 7-17 years. According to Center of Bucharest for Resources and Educational Assistance for the school year 2015-2016 in Romania were oriented mainstream schools a total of 350 children with special educational needs, and more than 1,200 children to special schools. Practitioners appreciate that their number is doubled that of children whose parents refuse undiagnosed or diagnosis ${ }^{2}$.

Inclusive society strengthens its existence under a coordinated and related social dynamics at social subsystems. In sociology, the functionalist paradigm systemic and explains this complex process of existence and operation of inclusive society. (Herbert Spencer, Emile Durkheim, Talcott Parsons, Robert King Merton, Alfred Reginald RadcliffeBrown, Bronislaw Malinowski, Niklas Luhmann, Gerhard Lenski.)

\section{INCLUSIVE SCHOOL, CONTEXT AND REVIEW OF LITERATURE}

„The concept of social inclusion "is a broad concept that supports the common sense explanation inclusion, insertion, acceptance, recognition and valorisation of the person or social group of which it forms part. In general, the explanation, social inclusion "is plastic assertions register a person subject integration and full recognition of the rights and liberties in concluding the social conditions on three levels: primary, secondary and tertiary. Legislation in Romania, operating with the concept of inclusion which it defines as follows: „The process of social inclusion comprises measures and multidimensional actions in the areas of social protection, employment, housing, education, health, information communication, mobility, security, justice and culture, to combat social exclusion and to ensure active participation people from all economic, social, cultural and political society ${ }^{\prime 3}$.

What is ,, School for All? "What are the determinants of its work here?

Discourse about inclusive school concern throughout Europe and beyond. At international level there were numerous interventions by various organizations campaigning for children's rights and that allowed the signing of agreements on recognizing and

\footnotetext{
${ }^{2}$ www.reninco.ro

${ }^{3}$ According to art. 6 lit. c) from Law no. 292/2011 - The Law for social assitence
} 
supporting the rights of children with disabilities. In accordance with the UN Convention on the Rights of the Child: ${ }^{4}$

„a child with physical or mental disabilities, must ensure a full and decent life in conditions that would ensure dignity, promote its autonomy and facilitate the child's active participation in the community". In this framework emphasizes the importance of the right to special care for children with disabilities, the right professional advice given to them and those in charge of their upbringing and schooling. Support for and aspects of securing effective access to education, training, health care and rehabilitation to promote social integration and personal development of children. The document stresses the importance of considering the size of the right to education is Statement from Salamanca $(2001)^{5}$.

, which states that every child has the fundamental right to education and special educational needs arising from the presence of a disability or learning difficulties". International classifications consider the following criteria for the classification of disability: somatic, physical, sensory, motor. In terms of learning difficulties speak: dyslexia, dyscalculia, dysgraphia, dyspraxia. Statement from Salamanca emphasizes that all children should benefit from child-centered pedagogy and access of disabled children to a regular school system with inclusive orientation. It also assigns an important role in promoting early childhood development and readiness for school

The United Nations Convention on the Rights of Persons with Disabilities (2006) reiterates the importance of compliance by Member States the principle of equal opportunities for this category of people further underlines the importance of recognizing access of education and hence the inclusive school. In 2010, Romania was drafted Law. 221 Convention for ratification.

\begin{abstract}
"The participating states recognize the right of persons with disabilities to participate equally with others in cultural life [...] to have the opportunity to develop and utilize their creative potential, artistic and intellectual, not only for their own benefit, but also to enrich the entire society; [...] to ensure that laws protecting intellectual property rights do not constitute a barrier to unreasonable and discriminatory access for people with disabilities to cultural materials [...] to recognize and support their linguistic and cultural rights, including sign language and culture people with hearing [...] to participate, on an equal basis with others, to recreation, leisure and sports [...] children with disabilities have equal access with other children in terms of participation games, recreation and leisure, sports activities, including the activities taking place in the school system",
\end{abstract}

According to the study conducted by the European Agency for Special Needs Education in the developmental and Eurydice ${ }^{7}$ on practices related to inclusive education in 30 European countries reveals that countries are promoting policies and inclusive practices, by providing services in inclusive schools such as Spain, Greece, Italy, Portugal, Sweden, Iceland, Norway and Cyprus; countries that are implementing different models of inclusive education and special such as Denmark, France, Ireland, Luxembourg, Austria, Finland, Great Britain, Latvia, Liechtenstein, Czech Republic, Estonia, Lithuania, Poland, Slovakia and Slovenia; of developed countries where educational systems are different: special education and inclusive education.

\footnotetext{
${ }^{4}$ Art. 23 (1) from Internationa Convention for Childs Rights $i$

${ }^{5}$ Statement from Salamanca, 2001

${ }^{6}$ Art. 30 from United Nations Convention for the rights of disabilities persons

${ }^{7}$ Special Needs Education In Europe (2003), European Agency for Development in Special Needs Education, and Eurydice, Brussels.
} 
For this case, organizing the education system is governed by special laws ${ }^{8}$. Recent statistical data, according to the World Health Organization (2016), reveals that the world identified a number of 1 billion persons with disabilities $(15 \%$ of the world's purse with some form of disability). Of these, half of them have no access to medical services. Of all people with disabilities, 100 million are children.

Regarding the interpretation of inclusive education perspective in national laws are different explanations. We present below an exhaustive interpretation. Thus, in Norway they have the right to special education students who do not or can not benefit sufficiently active teaching in mainstream education; they are entitled to special education. The structure of the courses offered must be achieved so as to benefit their appropriate relative to other students in relation to educational objectives realistic for them. Students receiving special education have the same total number of teaching hours as other pupils. Education experts established: the benefits of schooling in mainstream education, learning difficulties it has student and other special import conditions for teaching, student learning goals realistic; It also provides support for integration into mainstream education and identify appropriate. In the US, for a child is identified as a disabled person in the context of considering the level of educational performance were adversely affected, to be accessed special services. „To qualify for special education services, a student must demonstrate a disability in one of the 13 specific categories, including autism, developmental disabilities, specific learning disability, mental disorder, emotional and / or behavioral disability, speech and language disability, deafblind, visual impairment, hearing impairment, orthopedic disorders or physical health, other disorders (including attention deficit disorder), multiple disabilities and traumatic brain injury. "In England, children have special educational needs are considered children who have learning difficulties and need special education provision. It considers learning difficulty if: a) have a higher / significant difficulty to learn than most children of the same age or b) have a disability that prevents them from benefiting from the educational facilities provided by the school children of the same age the local education authority. A child has "special educational needs" if he has a learning difficulty which calls for special educational procedure for him. A child has a "learning difficulty" if it has difficulty significantly higher in learning than most children his age, he has a disability which either prevents him from making use of educational facilities of a kind provided the general age of the schools in the local education authority, or under compulsory school age, or if special educational provision was not made for him. Switzerland also advocates school for all schools.

Thus children and young people up to age 20 years, who live in Switzerland are entitled to special education services under the following conditions: previous compulsory education, if it can be that child development is limited or no risk of harm to future development and that the requirements of primary school children are hardly touched without additional support or during compulsory education, it has been established that development and education prospects are limited and need special educational support. In Sweden, there is a definition designed for expression, special educational needs". Thus, education is based on a "school for all" and focuses on access to education for all. This means that students who need special support or define not treated differently from other children and their rights are not specified separately. The school is required to reach all students' needs. Poland also gives us a framing and conceptualizing inclusive school. Thus, education for children with special needs refers to special needs children and youth with

8 Voicu, N., Baba, L. (coord). 2009. Report on the situation of inclusive education in Romania - 2007-2009, p. 10. Centrul Educația 2000+, Fundația de Abilitatre Speranța. 
developmental disabilities. The educational process requires a special organization of pedagogical work, working methods and equipment. This can take place in schools or special schools. Addresses: students with mild mental disabilities, students with moderate and severe mental disabilities, students with disabilities severe mental student's deaf students with deaf, blind or visually impaired, physically disabled, chronically ill, difficulties psychiatric with autism, with multiple disabilities with social and behavioral problems with speech and communication problems. Estonia is the country who appreciate the requirement in terms of educational or intellectual supradotării student performance compared to its biological age. Thus, students with special educational needs are students whose remarkable talent, learning difficulties or behavioral health problems, disability or long-term absence from studies creates the need to make changes or adjustments in the content of education, processes study or learning environment (study aids, classrooms, language communication, including alternative communication teachers and there are specially trained support staff.

\section{METHOD}

For the state of inclusive education in Romania, has conducted a case study that aimed to evaluate inclusive education policies in Romania in 2007-2017. They were designed following specific objectives: analysis of strategies of inclusive education policy; analysis of indicators on the coverage of the school-age population is identified as a population with special educational needs and integrated into mainstream education; analysis strategies for achieving process of school inclusion of people with special educational needs in schools in Romania.

Research methodology turned to the following research techniques: analysis of legal documents describing the policy of inclusion in mainstream education of children with special educational needs, secondary analysis of statistical data on the number of children with special educational needs integrated into mainstream education, analysis quality indicators specific integration into mainstream education of children with special educational needs.

\section{FINDINGS}

In Romania it adopted a series of measures and legislative packages to facilitate integration into mainstream education of children with special educational needs. In this context, it took into account the specific harmonization of domestic legislation with European and international framework (Jomtiem 1990 Declaration on Education for All, Standard Rules on Equal Opportunities for People with Disabilities, Statement from Salamanca 1994 World Declaration on Education for All Charter of Fundamental European2000 / C364 / 01 where in art. 21 and article 26 are specified aspects of non-discrimination and integration of people with disabilities Declaration E9 Statement "Education for All in 2000, adopted at the fourth summit of the first nine countries with the largest population "UN Convention on the Rights of persons with Disabilities in 2006 in national education according to law, according to OM 5573/2011, education for persons with special educational needs is realized in special and mainstream schools as forms of special education and special integrated preschool, primary, secondary, vocational, secondary and post for persons with special needs (deficiencies / disabilities / learning difficulties, impaired language and communication, social-affective and behavioral disorders).

Within public schools, the implementation of the educational work using specifically for each student considered student with special educational needs who designs a 
personalized plan and multidisciplinary plurisectoraială interent. Integration into mainstream education of children with special educational needs, according to current regulations, require resource centers and pedagogical assistance, grant from the assessments made of a certificate of school and professional orientation comprising: diagnosis / impairment, the degree of his / her.

Depending on this, children with special needs are oriented in mainstream education or in special education as follows: children with special needs integrated in mainstream education, mainstream education curriculum that follows; children with special needs integrated into special groups / classes organized in mainstream education; special needs children in special education; Special Needs children requiring hospitalization periods greater than 4 weeks are organized, as appropriate, group or class within the health unit where they are hospitalized; special needs children who, for medical reasons or because of a disability, are homebound, which is organized home schooling over a period of time.

To these and other measures are in place for granting various material benefits or financial support to keep people identified with special needs in the education system. As forms of support are identified: daily feed allowance and allowance for school supplies, bedding, clothing and footwear.

In Romania, according to statistics provided by National Authority for Child Protection and Adoption (ANPDCA) in June 2016, the situation of children with disabilities, certified, are as follows:

Table 1. The situation of children with disabilities in Romania according to the degree of disability

\begin{tabular}{|c|c|}
\hline Total children with disabilities , incuding & $\underline{71798}$ \\
\hline \hline disabled children enrolled in grade slightly & 1647 \\
\hline \hline disabled children enrolled in grade medium & 18910 \\
\hline \hline children involved in serious disabilities & 15001 \\
\hline \hline children involved in very serious disabilities & 36240 \\
\hline
\end{tabular}

Source: ANPDCA, Romania, 2017

Most children identified with disabilities increased and serious. To these children interventions require special education, complex package of measures (medical, educational, social), implemented through institutions (special schools or homes hospital, recovery, specialized care centers). The other part lies in the segment of children with disabilities and mild (around 19500 cases) and subject to interventions at specialized education in mainstream schools.

Table no 2. Children with disabilities by age

\begin{tabular}{|c|c|c|c|c|c|}
\hline \multirow[b]{2}{*}{ Disabilites category } & \multicolumn{5}{|c|}{ Age category } \\
\hline & 2 year & $\begin{array}{l}- \\
\text { years }\end{array}$ & -13 years & 17 years & $14-$ \\
\hline $\begin{array}{l}\text { disabled children enrolled in grade } \\
\text { slightly }\end{array}$ & 1 & 49 & & & 400 \\
\hline
\end{tabular}




\begin{tabular}{|c|c|c|c|c|}
\hline $\begin{array}{l}\text { disabled children enrolled in grade } \\
\text { medium }\end{array}$ & 43 & 531 & 933 & 4064 \\
\hline $\begin{array}{llll}\text { children } & \text { involved } & \text { in } & \text { serious } \\
\text { disabilities }\end{array}$ & 13 & 658 & 853 & 4353 \\
\hline $\begin{array}{l}\text { children involved in very serious } \\
\text { disabilities }\end{array}$ & 14 & 629 & 667 & 4287 \\
\hline TOTAL & 75 & 067 & 1000 & 7796 \\
\hline
\end{tabular}

\section{Source: ANPDCA, Romania, 2017}

The children that impose complex package of measures implemented, nurseries, kindergartens and mainstream schools are institutions that implement inclusive education programs. The fewer children are found in age group of 0-2 years to 7-13 years which requires supplementation specialists to intervene from an indisciplinary perspective on issue of special educational needs.

\section{DISCUSSION}

It can be seen that the legal provisions mentioned attaches great importance to compliance the principle supported equal opportunities for all and equal access to education to all children. In this context, educational policies encourage school attendance by providing various training aids or financial benefits to all categories of the identified children with special educational needs. Politically we can say that there are efforts. From interviews with teachers dealing with children with special education, to find that beyond educational policy efforts have demarcated a series of actions of education of the masses on the principle of equal opportunities for all. There were situations where these children are special,, "are exposed to labeling processes, marginalization and social exclusion. In these situations, teachers have the obligation modeling behavior of others towards tolerance, equality, acceptance and valuing the person and to achieve educational process to meet the needs of all learners. The strategies adopted at group level socio-educational are multiple: from the physical concerning adaptation space class or other spaces used for learning in the education and teaching concerning aspects customizing curriculum modification and its adaptation to the capacities of each child for developing descriptors progress and school performance according to the specific special needs ${ }^{9}$. Educational activities are conducted under clear design the aims of education.Adapting curriculum be made taking into account: support pedagogical recommendations, individualized education plan, national curriculum and methodological guidelines on curricular adaptations and Assessment of Educational Progress in the context of inclusive education. Individualizing instruction is a student-centered teaching approach based on learning its peculiarities

For children with special educational needs to consider the size of differentiated education aimed at training processes of adaptation to the peculiarities of psycho-behavioral, emotional and intellectual means of one or more students. Pre educational process is linked to the clarification by the teacher on matters covered by special requirements. In this context it needs to collaborate with specialists in other sectors that are empowered to clarify all aspects covered by specific requirements (needs, risks, opportunities, results). These include, in particular by: supporting teachers, social workers, psychologists, specialists.

\footnotetext{
${ }^{9}$ Anghel, G. A, 2017, Interventional partnerships in the Education of Children with Special Needs în Revista de Asistență Socială, nr. 1/2017, Editura Polirom.
} 


\section{CONCLUSIONS}

These perspectives to explain the education for people with special educational needs, taking into account the principle of equal opportunities to education for all. Inclusive school is school education that develops the conditions for an educational process that uses resources didactic materials according to their potential of each student and conducive to academic success. Learning can not be ensured only under multisector considering an intervention model in which specialists from various sectors (itinerant teachers, social pedagogues, psychologists, social workers, doctors, counselors, therapists) to intervene simultaneously. Adopt a personalized service determined according to the needs of each learner can successfully contribute to the progress of each person.

\section{BIBLIOGRAPHY:}

[1] Anghel, G. A. Interventional partnerships in the Education of Children with Special Needs în Revista de Asistență Socială, nr. 1/2017. Iași: Editura Polirom. [Interventional Partnerships in the Education of Children with Special Needs in the Journal of Social Work, no. 1/2017. Iaşi: Ed. Polirom]/

[2] Voicu, N., Baba, L. (coord). Raport cu privire la situația educației incluzive în Romania - 2007-2009. 2009, Centrul Educația 2000+, Fundaţia de Abilitatre Speranţa. [Report on the situation of inclusive education in Romania - 2007-2009. 2009, Education Center 2000+,]

[3] ***UNESCO, Declarația de la Salamanca şi cadrul de acțiune pentru educaţia persoanelor cu nevoi speciale adoptată la Conferința Mondială cu tema „Educaţia persoanelor cu nevoi speciale: acces și calitate", Salamanca, Spania, 7-10 iunie 1994. [The Salamanca Declaration and the Framework of Action for the Education of People with Special Needs adopted at the World Conference on "Education for Persons with Special Needs: Access and Quality", Salamanca, Spain, 7-10 June 1994]

[4] ***www.reninco.ro

[5] *** Law no. 292/2011 - The Law for social assitence

[6] ***International Convention for Childs Rights

[7] $* * *$ United Nations Convention for the rights of disabilities persons

[8] ***Special Needs Education In Europe (2003), European Agency for Development in Special Needs Education, and EURYDICE, Brussels.

[9] ***Hotărârea nr. 564/2017 privind modalitatea de acordare a drepturilor copiilor cu cerințe educaționale speciale școlarizaţi în sistemul de învăţământ preuniversitar, Romania [Decision no. $564 / 2017$ on the way of granting the rights of children with special educational needs enrolled in the pre-university education system, Romania]. 